\title{
Herbivory and climate interact serially to control monoterpene emissions from pinyon pine forests
}

\author{
Amy M. Trowbridge, ${ }^{1,5}$ Ryan W. Daly, $, 2,6$ Detlev Helmig, ${ }^{2}$ Paul C. Stoy, ${ }^{3}$ and Russell K. Monson ${ }^{4}$ \\ ${ }^{1}$ Department of Ecology and Evolutionary Biology, University of Colorado, Boulder, Colorado 80309 USA \\ ${ }^{2}$ Institute of Arctic and Alpine Research (INSTAAR), University of Colorado, Boulder, Colorado 80309 USA \\ ${ }^{3}$ Department of Land Resources and Environmental Sciences, Montana State University, Bozeman, Montana 59717 USA \\ ${ }^{4}$ School of Natural Resources and the Environment and Laboratory for Tree Ring Research, University of Arizona,
} Tucson, Arizona 85721 USA

\begin{abstract}
The emission of volatile monoterpenes from coniferous trees impacts the oxidative state of the troposphere and multi-trophic signaling between plants and animals. Previous laboratory studies have revealed that climate anomalies and herbivory alter the rate of tree monoterpene emissions. However, no studies to date have been conducted to test these relations in situ. We conducted a two-year field experiment at two semiarid sites dominated by pinyon pine (Pinus edulis) during outbreaks of a specialist herbivore, the southwestern tiger moth (Lophocampa ingens: Arctiidae). We discovered that during the early spring, when herbivory rates were highest, monoterpene emission rates were approximately two to six times higher from undamaged needles on damaged trees, with this increase in emissions due to $\alpha$ pinene, $\beta$-pinene, and camphene at both sites. During mid-summer, emission rates did not differ between previously damaged and undamaged trees at the site on the Western Slope of the Rocky Mountains, but rather tracked changes in the temperature and precipitation regime characteristic of the region. As the mid-summer drought progressed at the Eastern Slope site, emission rates were low, but differences between previously damaged and undamaged trees were not statistically significant. Despite no difference in emissions, mid-summer tissue monoterpene concentrations were significantly lower in previously damaged trees at both sites. With the onset of monsoon rains during late summer, emission rates from previously damaged trees increased to levels higher than those of undamaged trees despite the lack of herbivory. We conclude that (1) herbivory systemically increases the flux of terpenes to the atmosphere during the spring, (2) drought overrides the effect of past herbivory as the primary control over emissions during the mid-summer, and (3) a release from drought and the onset of latesummer rains is correlated with a secondary increase in emissions, particularly from herbivoredamaged trees, possibly due to a drought-delayed stimulation of induced monoterpene synthesis and/or increases in stomatal conductance. A greater understanding of the interactive effects of seasonality and herbivory on monoterpene emissions provides much needed information regarding the atmospheric and ecological consequences that these compounds will have for semiarid ecosystems.
\end{abstract}

Key words: drought; herbivory; monoterpenes; monsoons; Pinus edulis; pinyon-juniper woodlands; southern Rocky Mountains, USA; southwestern tiger moth, Lophocampa ingens; stomatal conductance; tri-trophic interactions; volatile organic compounds (VOCs).

\section{INTRODUCTION}

Conifers employ a number of defensive strategies against herbivorous pests, including the production of oleoresin that contains a diverse array of terpenoid compounds (Trapp and Croteau 2001). Monoterpenes $\left(\mathrm{C}_{10}\right)$ are the dominant secondary compound in conifer

Manuscript received 26 May 2013; revised 11 October 2013; accepted 18 October 2013; final version received 12 November 2013. Corresponding Editor: R. A. Raguso.

${ }^{5}$ Present address: Indiana University Department of Biology, 220 Jordan Hall, Bloomington, Indiana 47405 USA. E-mail: amtrowbr@indiana.edu

${ }^{6}$ Present address: U.S. Environmental Protection Agency, National Risk Management Research Laboratory, Research Triangle Park, North Carolina 27711 USA. resin, and while their volatility results in a fraction of the needle terpene pool escaping constitutively, insect damage can also affect emissions through induction and/or exposure of the internal needle structures to the atmosphere (Litvak and Monson 1998). Both constitutive and induced monoterpene emissions play important ecological roles by affecting herbivore preference and performance, mediating interactions between herbivores and their natural enemies, and influencing the oxidative capacity of the lower troposphere (see Yuan et al. 2009). Although the specific monoterpenes that are produced within different plant tissues are under genetic control, phenology (e.g., Schönwitz et al. 1990), temperature (e.g., Tingey et al. 1980), drought (Mattson and Haack 1987), and herbivory (e.g., Litvak 
and Monson 1998) can alter biosynthesis patterns and emissions to the atmosphere. Thus, understanding the primary environmental and biotic factors controlling monoterpene fluxes from plant tissues will enhance our ability to quantify their influence on ecological and atmospheric processes.

The concentration of monoterpenes within conifer needle tissues reflects a balance between the rates of biosynthesis and emissions. Two of the most important influences on this balance are (1) past herbivory, which can trigger biochemical reactions that induce tissues to increase the rate of biosynthesis, and (2) abiotic stresses, which can slow carbon assimilation and terpene biosynthesis rates and alter the rate of emissions. Despite past laboratory and single-factor field studies that have demonstrated the potential for controls by biotic and abiotic factors, few field studies have investigated the interactive effects of climate and herbivory on tissue concentration and emissions of monoterpenes in conifer forests.

The relative importance of environmental factors affecting defense prioritization by plants in the context of herbivory, namely episodic outbreaks, is unclear and rarely tested. Yet seasonal meteorological events may be important in determining herbivore-induced plant chemistry in natural systems. Seasonal environmental variability has been shown to significantly affect conifer foliar monoterpene levels (Hodges and Lorio 1975, Lorio and Sommers 1986, Schönwitz et al. 1990) and emission rates (Staudt et al. 1997), which may impact or be altered by previous or current herbivory (Hakola et al. 2006). One environmental factor that has demonstrated a strong temporal correlation with the occurrence of insect outbreaks is drought. Since the study of Mattson and Haack (1987), a mounting body of evidence has linked water stress to the susceptibility of plants to insect herbivory due to a significantly lower investment toward resin defenses (Waring and Cobb 1992, Cobb et al. 1997) [but note Hodges and Lorio (1975) and Lorio and Sommers (1986)]. Although studies have shown monoterpene emission rates to decrease dramatically under drought conditions (Llusià and Peñuelas 1998, Staudt et al. 2002, Lavoir et al. 2009), foliar concentrations of monoterpenes may not reflect the composition or emission rates of monoterpenes released into the atmosphere (Llusià and Peñuelas 1998). Plant responses to drought are also highly variable and species specific, and our knowledge of drought-mediated changes in plant secondary compounds and their influence on herbivores is lacking (Gutbrodt et al. 2011). Thus, understanding the abiotic and biotic controls over monoterpene production and emissions in situ can offer mechanistic explanations for herbivore population dynamics and ecosystem function.

Pinyon-juniper woodlands are the third largest vegetation type in the western United States (West 1999). These forests have experienced large-scale mor- tality events due to extreme drought conditions and associated insect outbreaks in the last decade, with subsequent shifts in pinyon-juniper ecosystem structure and function (Mueller et al. 2005). Long-term research conducted in pinyon-juniper woodlands provides insight into the complex dynamics that exist between climate, pinyon fitness, and some of the pinyon's associated insects, fungi, and microbes (Brown et al. 2001). In this study we address the issue as to how pinyons in the field respond both physiologically and chemically to climate and herbivory. We hypothesized that plant chemical responses to variation in herbivory and drought over time cause shifts in the primary control over pinyon monoterpene synthesis and emissions throughout the season, with important implications for atmospheric processes and higher trophic level interactions.

\section{Methods}

\section{Study species: the southwestern tiger moth}

The univoltine phytophagous southwestern tiger moth (Lophocampa ingens: Arctiidae) feeds primarily on Pinus edulis in the southern Rocky Mountains of Colorado, Utah, Arizona, and New Mexico, USA (Powell and Opler 2009). In typical years, extensive feeding in April and May is confined to one or two branches per infested tree, and new growth can be seen later in the season. There is no tissue damage from $L$. ingens during pupation in June. Following pupation, moths emerge and are in flight from late July through mid-August, during which time they mate and search for suitable host plants on which to oviposit. Caterpillars hatch from eggs and the larvae will begin feeding gregariously during the early fall, while simultaneously building silken tents in which they undergo an incomplete diapause. Thus, under suitable environmental conditions, caterpillars may emerge during the winter and feed, but the majority of their feeding takes place during the spring. Damage can become extensive during outbreaks and may extend to $25-100 \%$ of the tree, and in some cases may lead to mortality. Although the specific factors contributing to outbreak events are unknown, L. ingens populations are generally controlled by cold winter temperatures, pathogens, and the presence of their natural endoparasitoid enemy (Meteorus euschausiae: Bracondidae), which parasitizes first and second instars of this species early in the fall.

\section{Field study sites}

The two experimental sites were located in the pinyon-juniper woodlands of southern Colorado on either side of the Continental Divide during the 2008 and 2009 growing seasons (in 2008, $37.83^{\circ} \mathrm{N} 106.30^{\circ} \mathrm{W}$, elevation $2195 \mathrm{~m}$, hereafter "Eastern Slope"; in 2009, $38.30^{\circ} \mathrm{N} 107.83^{\circ} \mathrm{W}$, elevation $2130 \mathrm{~m}$, hereafter "Western Slope"). Both sites are characterized as semiarid, and experience hot summers and cold winters. The Western Slope experiences more evenly distributed 
precipitation throughout the year, whereas the Eastern Slope experiences a pronounced summer drought and receives the majority of its annual precipitation during the late July-August monsoon (Appendix A: Fig. A1). Air temperature and relative humidity were measured throughout each sampling period (HOBO U12 Temperature/Relative Humidity Data Logger, Onset, Cape Cod, Massachusetts, USA) and cumulative precipitation and average maximum temperatures for each site were obtained from the nearest NOAA weather station (data available online $)^{7}$.

To assess the effects of herbivore damage on pinyon physiology and chemistry throughout the season, we implemented a paired observational design selecting only trees that were $\sim 80$ years old and approximately $2-$ $2.5 \mathrm{~m}$ tall. Age was initially estimated by size and the presence of cones and was confirmed via coring after the completion of the experiment. A "damaged" pinyon, characterized by $\sim 25-30 \%$ top-needle damage incurred on the tree as a whole resulting from tiger moth feeding in May, was paired with an "undamaged" pinyon, characterized by no visible signs of defoliation by tiger moth larvae or other herbivore species. It is important to note that infested pinyons with this level of herbivore damage were chosen because they represent the average level of damage observed during an L. ingens outbreak. The paired trees were of similar age and size, experienced similar micrometeorological conditions (e.g., aspect, sunlight, wind), and were within $10 \mathrm{~m}$ of one another. Despite the potential for the next generation of tiger moths to feed on the same damaged trees in the fall, we did not observe repeated herbivory; thus, any responses measured during the end of the growing season were only due to early-season herbivory; herein, the phrase "previously damaged" refers only to damaged trees observed in May of the current year. Measurements were conducted on 14-19 May, 17-19 June, 17-20 July, 15-19 August, and 22-25 September 2008 in Saguache County (Eastern Slope) and on 20-22 May, 16-19 July, 17-19 August, and 17-19 September 2009 in Montrose County (Western Slope). No data were collected in June of 2009 from Montrose County. All samples and measurements were taken $\sim 1.5 \mathrm{~m}$ aboveground from the distal $10-15 \mathrm{~cm}$ of south-facing, sun-exposed branches, which included the previous-year and current-year growth. All measurements were carried out on sunny days from 09:00-15:00 h with damaged and undamaged pairs randomly chosen in both space and time for sampling within and between months. Gas exchange and volatile emissions were measured on three undamaged branches from the same trees across the study period $(n=8)$ from both damaged and undamaged treatment groups.

\footnotetext{
${ }^{7}$ http://www.ncdc.noaa.gov/oa/climate/stationlocator. html
}

\section{Leaf gas exchange and monoterpene volatile emissions sampling}

Leaf-level gas exchange was measured using a portable photosynthesis system with a conifer chamber (LI-6400, LICOR, Lincoln, Nebraska, USA) to obtain rates of net $\mathrm{CO}_{2}$ assimilation $(A)$ and stomatal conductance $\left(g_{\mathrm{s}}\right)$. Repeated measures were performed on the same trees each month by placing $\sim 4 \mathrm{~cm}$ of the terminal growth of each study branch in the conifer chamber and sealing around the branch with a silicone polymer (Silly Putty) to minimize leaks. After gas exchange measurements were made and volatile samples taken, branches were harvested and stored in paper bags for later determination of surface area using the method of Chen et al. (1997) for volume displacement (Appendix B) and dry mass.

Following gas exchange measurements, a dynamic headspace branch-level enclosure technique was used to measure monoterpene emissions (see Ortega et al. 2008) on the sample branches. Branch enclosure headspace chambers were created from polyamide nylon bags (oven bags of $1570 \mathrm{~cm}^{3}$; Reynolds, Richmond, Virginia, USA), with one end placed over a Teflon back plate fitted with stainless steel tubing connectors. A new bag was used for each branch. Each back plate was equipped with an $8 \mathrm{~cm}^{2} \times 2 \mathrm{~cm}$ fan enclosed in a custom Teflon casing (Jameco Electronics, Belmont, California, USA) and a two-channel air temperature and humidity data logger (HOBO U12 Temperature/Relative Humidity Data Logger, Onset, Cape Cod, Massachusetts, USA); see Appendix C. Ambient air and needle temperature were measured just prior to volatile sampling using the LI-6400. While the pumps were running, the end of the oven bag not secured to the back plate was placed over the same branch sections measured for gas exchange and fastened around a portion of the branch using zip ties. Once enclosed, we allowed the chamber to equilibrate for 10 minutes at a flow rate of $1 \mathrm{~L} / \mathrm{min}$. This relatively short sampling time was due to the experimental limitations of battery power in remote field sites and to avoid extreme temperatures $\left(>40^{\circ} \mathrm{C}\right)$ that could be reached in the chamber at longer sampling times. In 2008 on the Eastern Slope, average temperatures reached in the chamber and the average temperature of the ambient air, respectively, were $27.8^{\circ} \mathrm{C}$ and $26.1^{\circ} \mathrm{C}$ (May), $31.8^{\circ} \mathrm{C}$ and $30.2^{\circ} \mathrm{C}$ (June), $30.3^{\circ} \mathrm{C}$ and $29.8^{\circ} \mathrm{C}$ (July), $24.2^{\circ} \mathrm{C}$ and $23.4^{\circ} \mathrm{C}$ (August), and $24.4^{\circ} \mathrm{C}$ and $23.5^{\circ} \mathrm{C}$ (September). From pinyon pines on the Western Slope in 2009, average temperatures reached in the chamber and the surrounding ambient air, respectively, were $24.6^{\circ} \mathrm{C}$ and $22.7^{\circ} \mathrm{C}$ (May), $29.1^{\circ} \mathrm{C}$ and $26.4^{\circ} \mathrm{C}$ (July), $30.1^{\circ} \mathrm{C}$ and $26.7^{\circ} \mathrm{C}$ (August), and $15.9^{\circ} \mathrm{C}$ and $14.2^{\circ} \mathrm{C}$ (September). In 2008, chamber temperatures never exceeded $40^{\circ} \mathrm{C}$ (maximum chamber temperature observed was $38.5^{\circ} \mathrm{C}$ in July), whereas in 2009 , the average chamber temperature only exceeded $40^{\circ} \mathrm{C}$ twice $\left(40.4^{\circ} \mathrm{C}\right.$ in July and $41.7^{\circ} \mathrm{C}$ in August). In addition to adhering to the enclosure size, purge flows, and sampling times 
required to reach $95 \%$ steady state values, as described in Ortega et al. 2008, preliminary testing using pinyon seedlings and a proton transfer reaction-mass spectrometer (PTR-MS; Ionican Analytik, Innsbruck, Austria) assured us that the time allowed for equilibration and sampling was adequate to record steady state emission rates. Air entering the chamber through a doubleheaded diaphragm pump was scrubbed of volatile organic compounds (VOCs) and ozone using activated charcoal (Alltech Associates, Deerfield, Illinois, USA) and $\mathrm{MnO}_{2}$ coated net ozone scrubbers (O.B.E. Corporation, Fredericksburg, Texas, USA), respectively.

Monoterpenes were sampled onto custom-made glass adsorbent cartridges (borosilicate glass; Allen Scientific, Boulder, Colorado, USA) packed with $\sim 0.25 \mathrm{~g}$ Tenax GR adsorbent (20/35 mesh, Alltech Associates, Deerfield, Illinois, USA) between plugs of quartz wool at a sample flow rate of $150 \mathrm{~mL} / \mathrm{min}$ for 10 minutes. All flow rates were set and controlled using mass flow controllers (MKS Instruments, Methuen, Massachusetts, USA). Immediately following sampling, the cartridge samples were capped with Swagelok fittings, transported at $0^{\circ} \mathrm{C}$ back to the lab, and stored in a $-20^{\circ} \mathrm{C}$ freezer for chemical analysis (Appendix D). Subsamples of current and one-year-old pinyon needles were removed from the sample branches after all VOC and physiological measurements, flash frozen, and brought back to the lab for foliar chemical analysis (Appendix E).

\section{Statistical analyses}

All statistical analyses were performed using SAS statistical software (SAS Institute, Cary, North Carolina, USA) and data from each field site were assessed individually. Gas exchange data from both sites were normally distributed and analyzed using a mixed-model repeated-measures ANOVA (proc mixed), with treatment (herbivory) as a fixed main effect and the repeated statement including time, compound symmetry covariance structure, tree as the subject, and a Bonferroni correction. The basal emission rates (BER) calculated from the measured emission rates (ER) are intended as a measure with the temperature and incident light intensity at constant values and are referenced to observations made at $30^{\circ} \mathrm{C}$ leaf temperature and 1000 $\mu \mathrm{mol} \cdot \mathrm{m}^{-2} \cdot \mathrm{s}^{-1}$ photosynthetic photon flux density (see Appendix D: Eq. D.4). Total and individual monoterpene BER and ER data from both sites were logtransformed, whereas foliar concentrations met the assumptions of normality. BER, ER, and concentration data were analyzed using a repeated-measures ANOVA, as described previously, with a Bonferroni correction, and relative humidity was included as a covariate when analyzing the emission data. We used one-way ANOVAs with a Bonferroni correction and tree as the random effect to assess differences in the concentration, BER, and ER of individual compounds between damaged and undamaged trees each month.

\section{Results \\ Effects of herbivory and seasonal variation on photosynthesis and stomatal conductance in Pinus edulis}

$\mathrm{CO}_{2}$ assimilation rate $(A)$ and stomatal conductance $\left(g_{\mathrm{s}}\right)$ on the Western Slope varied across the growing season (Fig. 1A, C; for $A, F_{3,100}=36.32$; for $g_{\mathrm{s}}, F_{3,100}=$ 30.53, $P<0.0001$ ), with trees exhibiting the highest $A$ during periods of relatively cool temperatures in May and September, and lower $A$ during July and August when daytime temperatures exceeded $30^{\circ} \mathrm{C}$. Herbivory had no significant effects on pinyon $A$ or $g_{\mathrm{s}}$ on the Western Slope (Fig. 1A, C; for $A, F_{1,18}=1.62$; for $g_{\mathrm{s}}$, $\left.F_{1,18}=0.80, P>0.05\right)$, and there was no interactive effect of time and herbivory on $A$ or $g_{\mathrm{s}}$ (for $A, F_{3,100}=$ $1.28, P=0.28$; for $g_{\mathrm{s}}, F_{3,100}=2.03, P=0.12$ ).

Values for $A$ and $g_{\mathrm{s}}$ of pinyons changed as the season progressed on the Eastern Slope (Fig. 1B, D; for $A$, $F_{4,162}=19.23$; for $g_{\mathrm{s}}, F_{4,162}=18.72, P<0.0001$ ), although the seasonal pattern was different than that exhibited on the Western Slope. In undamaged pinyons, $A$ decreased from May until July, concurrent with progressively greater temperatures and lack of precipitation, whereas the highest rates were observed in August after the onset of the late-summer monsoons. This sharp increase was then followed by a decline in $A$ and $g_{\mathrm{s}}$ such that observed values in May and September were similar. Rather than decreasing from spring to summer, $A$ in herbivore-damaged pinyons remained similar until the late-summer monsoons, at which point it tracked the same pattern as that for undamaged pinyons. Similar to observations on the Western Slope, Eastern Slope $A$ and $g_{\mathrm{s}}$ were not significantly affected by herbivore damage (Fig. 1B, D; for $A, F_{1,16}=1.32, P=$ 0.27 ; for $g_{\mathrm{s}}, F_{1,16}=3.05, P=0.10$ ), but there was a significant interactive effect of time and herbivory on both (for $A, F_{4,162}=2.99, P<0.05$; for $g_{\mathrm{s}}, F_{4,162}=2.56$, $P<0.05)$.

\section{Seasonal variation of total monoterpene emissions in herbivore-damaged and undamaged pinyons}

Total monoterpene emission rates (ERs) of the Western Slope pinyons, shown in Fig. 2A, were significantly affected by seasonal variability $\left(F_{3,114}=\right.$ 34.22, $P<0.0001)$, as were the calculated basal emission rates (BERs) (Appendix F: Fig. F1A; $F_{3,114}=6.41, P<$ 0.0005). Although herbivory alone did not have a significant effect on measured ERs or calculated BERs $\left(F_{1,15}=1.22, P=0.29 ; \quad F_{1,15}=0.04, \quad P=0.84\right.$, respectively), probably due to similar emissions between damaged and undamaged trees throughout most of the growing season, there was an interactive effect of herbivory and time (for ER, $F_{3,114}=7.31, P<0.0005$; for BER, $\left.F_{3,114}=3.86 P<0.01\right)$. Concurrent with herbivore feeding during May, damaged pinyons exhibited total monoterpene ERs about two to three times higher than their undamaged counterparts; all data are reported as mean $\pm \mathrm{SE}$. For damaged pinyons, ER $=$ 

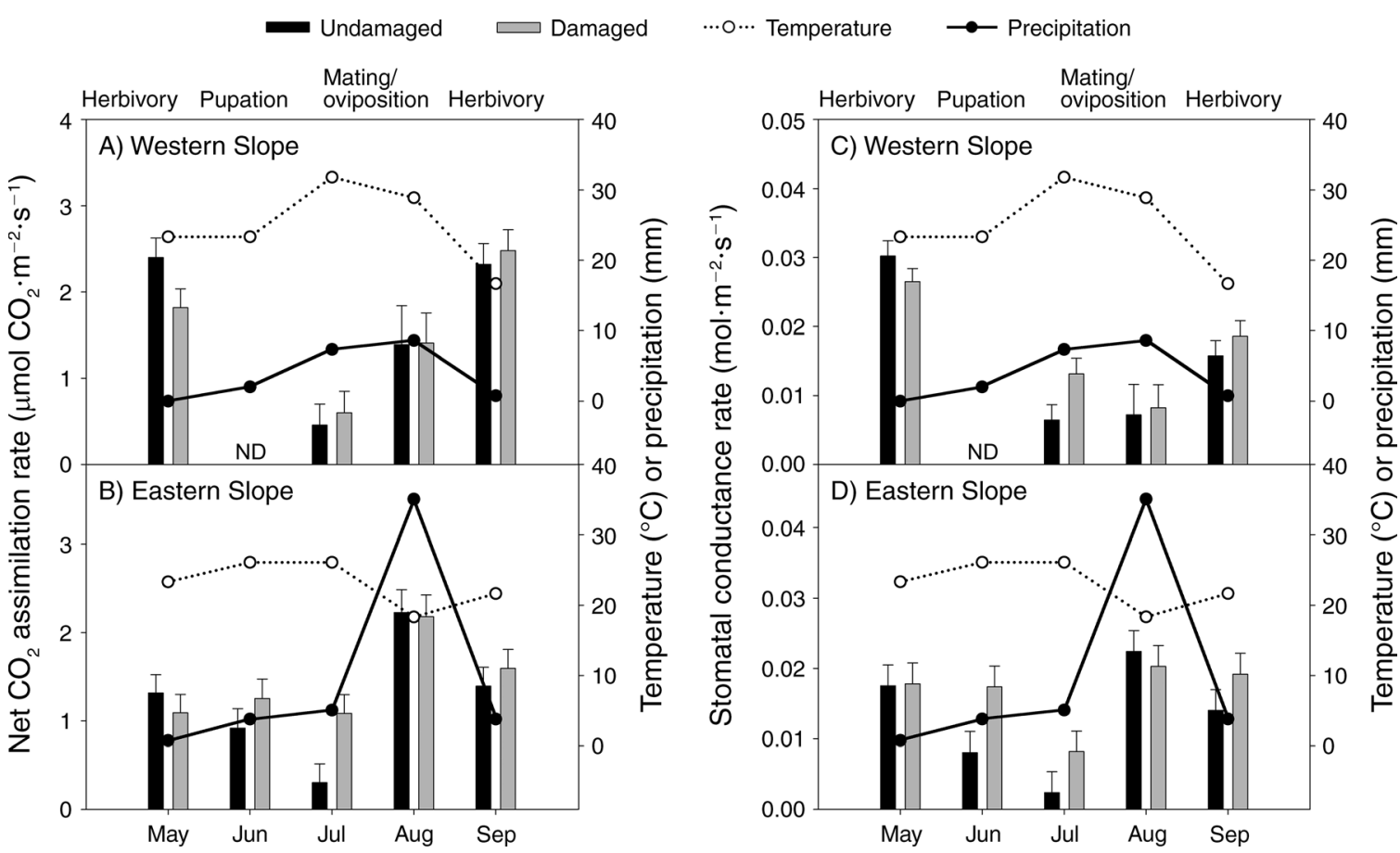

FIG. 1. Seasonal change in (A, B) net $\mathrm{CO}_{2}$ assimilation rates, A, and (C, D) stomatal conductance rates, $g_{c}$, of Pinus edulis, either undamaged or damaged by the southwestern tiger moth Lophocampa ingens, at sites on the Western Slope (upper panels) and Eastern Slope (lower panels) of the Rocky Mountains in southern Colorado, USA. Values are means + SE $(n=8$ trees). ND represents no data. Herbivore feeding, pupation, and mating/oviposition seasonal periods are noted at the top; although herbivory does occur in the fall, we did not observe repeated herbivory during our study. Precipitation values (solid circles) represent cumulative precipitation two weeks prior to sampling and temperature values (open circles) represent the mean maximum daily temperature at each site during sampling.

$1.05 \pm 0.10 \mu \mathrm{g} \cdot[\mathrm{g} \text { dry } \mathrm{mass}]^{-1} \cdot \mathrm{h}^{-1}$; for undamaged pinyons, $\mathrm{ER}=0.34 \pm 0.11 \mu \mathrm{g} \cdot[\mathrm{g} \text { dry } \mathrm{mass}]^{-1} \cdot \mathrm{h}^{-1}(P<$ $0.0005)$. For damaged pinyons, BER $=1.67 \pm 0.15 \mu \mathrm{g} \cdot[\mathrm{g}$ dry mass $]^{-1} \cdot \mathrm{h}^{-1}$; for undamaged pinyons, BER $=0.80 \pm$ $0.16 \mu \mathrm{g} \cdot[\mathrm{g} \text { dry mass }]^{-1} \cdot \mathrm{h}^{-1}$. Although ERs from damaged trees did not change significantly into July $(1.06 \pm 0.22$ $\left.\mu \mathrm{g} \cdot[\mathrm{g} \text { dry mass }]^{-1} \cdot \mathrm{h}^{-1}\right)$, undamaged trees exhibited significantly higher total emission rates $(1.14 \pm 0.23$ $\left.\mu \mathrm{g} \cdot[\mathrm{g} \text { dry mass }]^{-1} \cdot \mathrm{h}^{-1} ; P<0.005\right)$ in response to the same high temperatures and relatively high levels of precipitation to which damaged trees were exposed. These high rates were then followed by a gradual decrease in total monoterpene emissions from both damaged and undamaged pinyons, with the lowest ERs observed in September (ER damaged, $0.14 \pm 0.05 \mu \mathrm{g} \cdot[\mathrm{g}$ dry mass $]^{-1} \cdot \mathrm{h}^{-1}$; ER undamaged, $0.17 \pm 0.05 \mu \mathrm{g} \cdot[\mathrm{g}$ dry mass $]^{-1} \cdot h^{-1}$ ). The same seasonal trends were also observed for BERs, with the exception that while emissions were still low in September, they were not significantly lower than those observed in August.

Measured total monoterpene ERs (shown in Fig. 2B) and calculated total monoterpene BERs (Appendix F: Fig. F1B) from Eastern Slope pinyons were significantly affected by herbivory (for ER, $F_{1,18}=10.76, P<0.005$; for BER, $F_{1,18}=16.4, P<0.005$ ), time (for ER, $F_{4,150}=$ $14.78, P<0.0001$; for BER, $\left.F_{4,150}=35.07, P<0.001\right)$, and the interaction between these two main effects (for
ER, $F_{4,150}=4.29, P<0.005$; for BER, $F_{4,150}=4.12, P$ $<0.005)$. In May, trees that were experiencing herbivore damage emitted monoterpenes at a rate about six times greater than undamaged pinyons (for ER damaged, 2.74 $\pm 0.45 \mu \mathrm{g} \cdot[\mathrm{g} \text { dry mass }]^{-1} \cdot \mathrm{h}^{-1}$; for ER undamaged, $0.43 \pm$ $\left.0.43 \mu \mathrm{g} \cdot[\mathrm{g} \text { dry mass }]^{-1} \cdot \mathrm{h}^{-1} ; P<0.05\right)$. From June through July, there was no difference in total monoterpene ERs between damaged and undamaged trees, with the lowest emissions observed during the mid-summer drought in July (ER damaged, $0.26 \pm 0.07 \mu \mathrm{g} \cdot[\mathrm{g}$ dry mass $]^{-1} \cdot h^{-1}$; ER undamaged, $0.35 \pm 0.07 \mu \mathrm{g} \mathrm{gdw}^{-1} \mathrm{~h}^{-1}$ ). With the onset of the late-summer monsoons in August and a release from drought stress, Eastern Slope pinyons emitted higher levels of total monoterpenes compared to rates observed in June and July $(P<0.0001)$, and trees that had been damaged earlier in the season had significantly higher ERs than undamaged pinyons (ER damaged, $1.53 \pm 0.22 \mu \mathrm{g} \cdot[\mathrm{g} \text { dry mass }]^{-1} \cdot \mathrm{h}^{-1}$; ER undamaged, $0.82 \pm 0.24 \mu \mathrm{g} \cdot[\mathrm{g} \text { dry mass }]^{-1} \cdot \mathrm{h}^{-1} ; P<$ 0.05 ). This burst in monoterpene emissions was followed by a decrease in September, and monoterpene emissions between damaged and undamaged pinyons were not significantly different (damaged, $0.76 \pm 0.13 \mu \mathrm{g} \cdot[\mathrm{g}$ dry mass $]^{-1} \cdot \mathrm{h}^{-1} ;$ undamaged, $0.57 \pm 0.13 \mu \mathrm{g} \cdot[\mathrm{g}$ dry mass $\left.]^{-1} \cdot \mathrm{h}^{-1} ; P=0.10\right)$. The same seasonal trends were also observed for total BERs. 

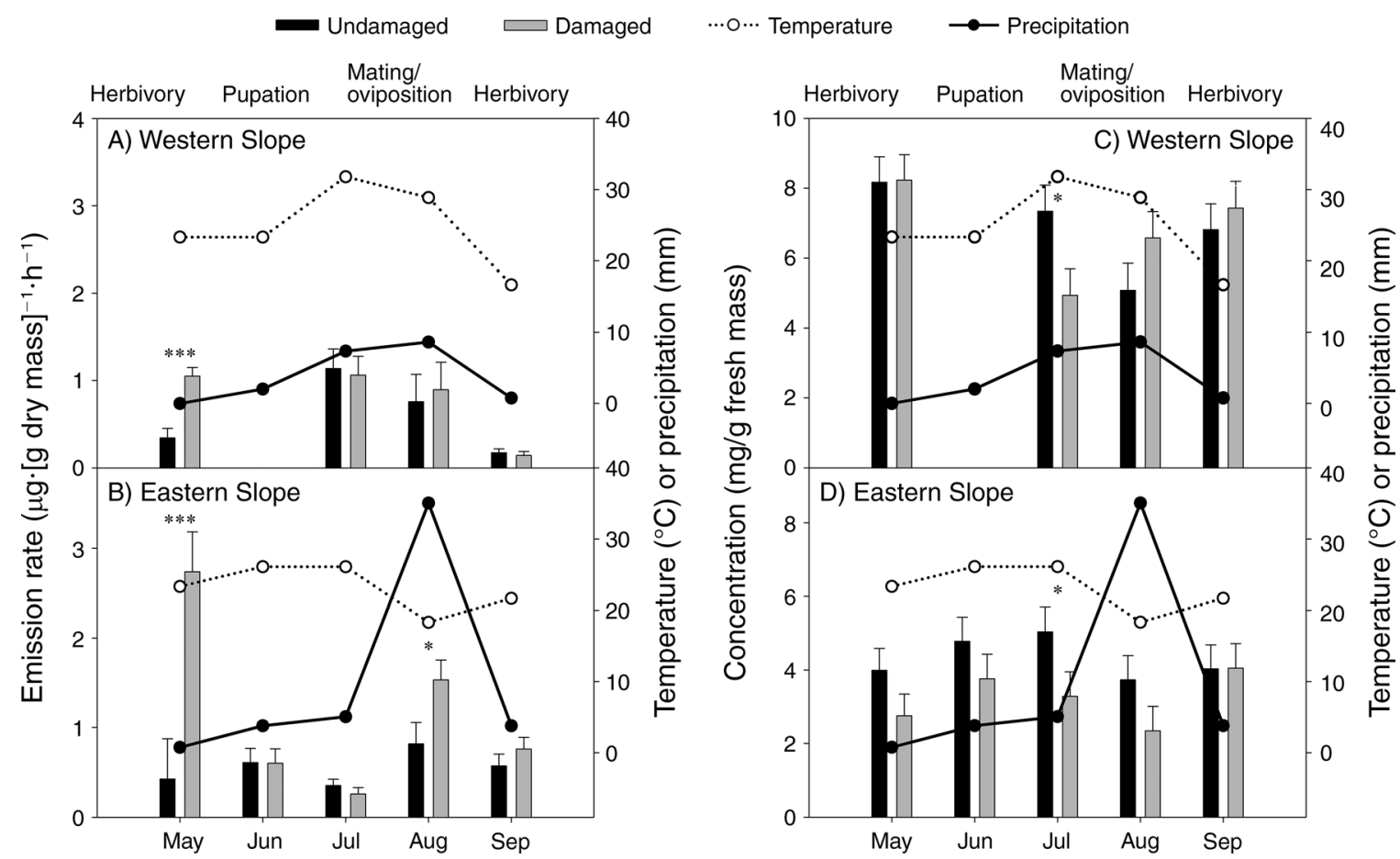

FIG. 2. Seasonal change in total monoterpene (A, B) emission rates (ERs) and (C, D) foliar concentrations of undamaged and Lophocampa ingens-damaged Pinus edulis at sites on the Western Slope (upper panels) and Eastern Slope (lower panels) of the Rocky Mountains in southern Colorado. Values are means $+\mathrm{SE}(n=8$ trees). ND represents no data. Herbivore feeding, pupation, and mating/oviposition periods are noted at the top; although herbivory does occur in the fall, we did not observe repeated herbivory during this time in our study. Total monoterpene emissions represent the sum of emissions from $\alpha$-pinene, $\beta$-pinene, $\beta$ myrcene, $\beta$-phellandrene, camphene, $\delta$-carene, and limonene. Total foliar concentrations represent the sum of monoterpene enantiomers $(+)$ - $\alpha$-pinene, $(-)$ - $\alpha$-pinene, $\beta$-pinene, $\beta$-myrcene, $\beta$-phellandrene, camphene, and $(-)$-limonene. Precipitation values (solid circles) represent cumulative precipitation two weeks prior to sampling and temperature values (open circles) represent the mean maximum daily temperature at each site during sampling.

$* P<0.05$; *** $P<0.001$; significant difference between treatments.

\section{Seasonal variation of individual monoterpene emissions in herbivore-damaged and undamaged pinyons}

We evaluated the impacts of herbivory and time on the ERs (Table 1) and BERs (Appendix G: Table G1) of seven individual monoterpene compounds between undamaged and herbivore-damaged pinyons each month throughout the season. In May, damaged trees on the Western Slope emitted significantly higher levels of $\alpha$-pinene, $\beta$-pinene, $\beta$-phellandrene, and camphene (and also limonene when considering BERs). Damaged trees on the Eastern Slope had elevated emission rates of $\alpha$-pinene, $\beta$-pinene, $\beta$-myrcene, camphene, and limonene (and also $\delta$-carene when considering BERs); data are reported as mean $\pm \mathrm{SE}$. In July, trees on the Western Slope that were previously damaged emitted higher levels of $\beta$-phellandrene (damaged, $0.06 \pm 0.01 \mu \mathrm{g} \cdot[\mathrm{g}$ dry mass $]^{-1} \cdot \mathrm{h}^{-1}$; undamaged, $0.02 \pm 0.01 \mu \mathrm{g} \cdot[\mathrm{g}$ dry mass $]^{-1} \cdot \mathrm{h}^{-1} ; P<0.05$ ), although no difference was observed in the BERs or in the total monoterpene emission rates between treatments (Appendix G: Table G1 and Fig. 2A, respectively). Previously damaged trees on the Eastern Slope emitted higher levels of $\alpha$-pinene (damaged, $1.04 \pm 0.17 \mu \mathrm{g} \cdot[\mathrm{g} \text { dry mass }]^{-1} \cdot \mathrm{h}^{-1}$; undam- aged, $\left.0.50 \pm 0.18 \mu \mathrm{g} \cdot[\mathrm{g} \text { dry mass }]^{-1} \cdot \mathrm{h}^{-1} ; P<0.05\right)$ and $\delta$-carene (damaged, $0.15 \pm 0.02 \mu \mathrm{g} \cdot[\mathrm{g} \text { dry mass }]^{-1} \cdot \mathrm{h}^{-1}$; undamaged, $0.05 \pm 0.02 \mu \mathrm{g} \cdot[\mathrm{g} \text { dry mass }]^{-1} \cdot \mathrm{h}^{-1} ; P<$ 0.05 ) during the monsoon rains in August, which was also seen in the calculated BERs and was observed in September as well (Appendix G: Table G1).

\section{Seasonal variation of total monoterpene foliar concentrations in herbivore-damaged and undamaged pinyons}

Total foliar monoterpene concentration of pinyons on the Western Slope (shown in Fig. 2C) was significantly affected by time $\left(F_{3,102}=26.71, P<0.0001\right)$ and the interaction between herbivory and time $\left(F_{3,102}=18.38\right.$, $P<0.0001)$, but not by herbivory alone $\left(F_{1,14}=0.04, P\right.$ $=0.84)$. Although $L$. ingens feeding in May resulted in significantly higher total monoterpene emission rates (Fig. 2A), there was no difference in foliar concentrations between herbivore-damaged and undamaged pinyons (Fig. 2C). Total monoterpene concentrations in undamaged pinyons during July $(7.34 \pm 0.74 \mathrm{mg} / \mathrm{g}$ fresh mass) were unchanged from those measured in May $(8.17 \pm 0.73 \mathrm{mg} / \mathrm{g}$ fresh mass), yet pinyons that had been previously damaged exhibited an approximately 
$40 \%$ decrease in total foliar monoterpene concentration (May, $8.23 \pm 0.73 \mathrm{mg} / \mathrm{g}$ fresh mass; July, $4.94 \pm 0.75$ $\mathrm{mg} / \mathrm{g}$ fresh mass; $P<0.0001$ ), and had significantly lower concentrations than observed in undamaged pinyons $(P<0.05)$. Foliar concentrations of undamaged pinyons decreased in August $(5.08 \pm 0.77 \mathrm{mg} / \mathrm{g}$ fresh mass; $P<0.0001)$, with a significant increase to mid-summer levels in September $(6.8 \pm 0.74 \mathrm{mg} / \mathrm{g}$ fresh mass; $P<0.001)$, whereas previously damaged trees experienced a steady increase in foliar monoterpenes into the fall (August, $6.57 \pm 0.75 \mathrm{mg} / \mathrm{g}$ fresh mass; September, $7.4 \pm 0.77 \mathrm{mg} / \mathrm{g}$ fresh mass; $P<0.01$; see Fig. 2C) with a concurrent decrease in monoterpene emissions (Fig. 2A).

Pinyons on the Eastern Slope exhibited changes in monoterpene foliar concentrations over time (Fig. 2D; $F_{4,66}=11.54, P<0.0001$ ), yet did not experience altered monoterpene foliar content as a result of herbivory $\left(F_{1,14}=2.66, P=0.13\right)$ or the interaction between herbivory and time $\left(F_{4,66}=1.61, P=0.18\right)$. Total monoterpene concentration in undamaged pinyons was highest in July, and significantly greater than the level observed in previously damaged pinyons (damaged, 3.28 $\pm 0.67 \mathrm{mg} / \mathrm{g}$ fresh mass; undamaged, $5.04 \pm 0.68 \mathrm{mg} / \mathrm{g}$ fresh mass; $P<0.05)$. A sharp increase in monoterpene emissions occurred for both damaged and undamaged pinyons with the onset of monsoon rains (Fig. 2B), while foliar monoterpene concentration significantly decreased in both sets of trees (Fig. 2D; damaged, 2.34 $\pm 0.67 \mathrm{mg} / \mathrm{g}$ fresh mass; undamaged, $3.73 \pm 0.66 \mathrm{mg} / \mathrm{g}$ fresh mass; $P<0.05$ ). Undamaged pinyons maintained similar total levels of foliar monoterpene concentrations into September $(4.03 \pm 0.65 \mathrm{mg} / \mathrm{g}$ fresh mass $)$, but foliar monoterpene concentrations in previously damaged trees increased significantly $(4.05 \pm 0.67 \mathrm{mg} / \mathrm{g}$ fresh mass; $P<0.0005)$, reaching levels observed in undamaged trees.

\section{Seasonal variation of individual foliar monoterpene concentrations in herbivore-damaged and undamaged pinyons}

All seven monoterpene enantiomers that were quantified from pinyon needles (Table 2) changed significantly over time on the Western Slope $\left(F_{3,102}=8.15, P\right.$ $<0.0001)$ and were affected by the interactive effect of herbivory and time $\left(F_{3,102}=4.61, P<0.0001\right)$, with the exception of camphene, which only changed over time $\left(F_{3,102}=12.44, P<0.0001\right)$. While $\delta$-carene was detected in the samples, it exhibited very similar elution times with $\beta$-pinene, often causing the less abundant, almost negligible, $\delta$-carene (RT 8.54) to elute as a shoulder to the much larger $\beta$-pinene peak (RT 8.41) and become indistinguishable from the baseline. Therefore, it was only possible to accurately integrate the $\beta$ pinene peak and no values for $\delta$-carene are subsequently reported. There was no difference in individual compound concentrations between damaged and undamaged pinyons throughout the growing season except for observations made in July, where previously damaged trees had significantly lower levels of $\beta$-myrcene (damaged, $0.48 \pm 0.11 \mathrm{mg} / \mathrm{g}$ fresh mass; undamaged, $0.90 \pm 0.11 \mathrm{mg} / \mathrm{g}$ fresh mass; $P<0.05)$ and $\beta$ phellandrene (damaged, $0.07 \pm 0.02 \mathrm{mg} / \mathrm{g}$ fresh mass; undamaged, $0.13 \pm 0.02 \mathrm{mg} / \mathrm{g}$ fresh mass; $P<0.05)$.

There was no difference in foliar concentrations in Eastern Slope pinyons of $(-)$ - $\alpha$-pinene, $(+)$ - $\alpha$-pinene, $\beta$ pinene, $\beta$-phellandrene, or camphene between undamaged and damaged trees throughout the season (Table 2 ), and only $\alpha$-pinene and $\beta$-phellandrene were significantly affected by time $\left(F_{4,66}=13.52, F_{4,66}=9.91\right.$, respectively, $P<0.0001)$. Concentrations of $\beta$-myrcene changed both over the season $\left(F_{1,15}=14.26, P<0.005\right)$ and in response to herbivory $\left(F_{4,66}=15.19, P<0.0001\right)$. Herbivore-damaged pinyons sustained significantly lower levels of $\beta$-myrcene from late spring to early fall $(P<$ $0.05)$. Although this difference was consistent throughout the year, it only translated into changes in total monoterpene concentration during mid-summer (Fig. 2D). Levels of (-)-limonene in damaged pinyons (0.06 \pm $0.02 \mathrm{mg} / \mathrm{g}$ fresh mass) were significantly lower than those of undamaged trees $(0.13 \pm 0.02 \mathrm{mg} / \mathrm{g}$ fresh mass $)$ during caterpillar feeding in May $(P<0.05)$.

\section{DisCUSSION}

Although a number of studies have explored the effects of abiotic stress on pinyon herbivore susceptibility (Cobb et al. 1997, Brown et al. 2001), our study is the first to consider the interactive effects of natural climate variation and folivory on monoterpene concentrations and emissions from pinyons in situ. Our results offer a clearer understanding of the trade-offs that occur between primary controls over plant chemistry in a species adapted to semiarid conditions, by showing how herbivory and drought individually and interactively affect pinyon monoterpene emissions over time. The results of this study have led us to three major conclusions: (1) early-spring herbivory by tiger moth larvae increases the flux of monoterpenes to the atmosphere, (2) drought overrides the effect of past herbivory as the primary control over emissions during the mid-summer, and (3) late-summer rains are correlated with a secondary increase in emissions, particularly in herbivore-damaged trees.

\section{Controls over seasonal patterns of monoterpene emissions and concentrations}

We observed sharp increases in total monoterpene emission rates during periods of herbivore feeding at both sites. Because we measured undamaged branches that shared vascular connections to damaged branches, we assume these responses to be systemic and that they cannot be explained via decreased diffusive resistance resulting from mechanical exposure of oleoresin sources to the atmosphere (Litvak et al. 1999, Loreto et al. 2000). Total monoterpene emission rates from damaged Eastern Slope pinyons increased about sixfold as 
TABLE 1. Measured monoterpene emission rates, ER $\left(\mu \mathrm{g} \cdot[\mathrm{g} \text { dry mass }]^{-1} \cdot \mathrm{h}^{-1}\right.$, mean $\left.\pm \mathrm{SE}\right)$, from undamaged and herbivoredamaged Pinus edulis trees throughout the 2009 growing season on the Western Slope and 2008 growing season on the Eastern Slope of the Rocky Mountains in southern Colorado, USA.

\begin{tabular}{|c|c|c|c|c|c|c|}
\hline \multirow{2}{*}{$\begin{array}{l}\text { Monoterpene } \\
\text { and location }\end{array}$} & \multicolumn{2}{|c|}{ May } & \multicolumn{2}{|c|}{ June } & \multicolumn{2}{|c|}{ July } \\
\hline & Undamaged & Damaged & Undamaged & Damaged & Undamaged & Damaged \\
\hline \multicolumn{7}{|l|}{$\alpha$-pinene } \\
\hline Western & $0.21 \pm 0.07$ & $\mathbf{0 . 6 3} \pm \mathbf{0 . 0 7}$ & ND & ND & $0.73 \pm 0.16$ & $0.71 \pm 0.16$ \\
\hline Eastern & $0.17 \pm 0.21$ & $1.20 \pm 0.21$ & $0.28 \pm 0.07$ & $0.31 \pm 0.07$ & $0.18 \pm 0.04$ & $0.12 \pm 0.04$ \\
\hline \multicolumn{7}{|l|}{$\beta$-pinene } \\
\hline Western & $0.02 \pm 0.02$ & $0.14 \pm 0.02$ & ND & ND & $0.06 \pm 0.02$ & $0.06 \pm 0.01$ \\
\hline Eastern & $0.10 \pm 0.09$ & $0.49 \pm 0.09$ & $0.06 \pm 0.01$ & $0.05 \pm 0.01$ & $0.03 \pm 0.01$ & $0.03 \pm 0.01$ \\
\hline \multicolumn{7}{|l|}{$\beta$-myrcene } \\
\hline Western & $0.04 \pm 0.01$ & $0.06 \pm 0.01$ & ND & ND & $0.16 \pm 0.04$ & $0.13 \pm 0.04$ \\
\hline Eastern & $0.02 \pm 0.05$ & $0.32 \pm 0.05$ & $0.06 \pm 0.02$ & $0.06 \pm 0.02$ & $0.04 \pm 0.01$ & $0.02 \pm 0.01$ \\
\hline \multicolumn{7}{|l|}{$\beta$-phellandrene } \\
\hline Western & $0.02 \pm 0.01$ & $0.08 \pm 0.01$ & ND & ND & $0.06 \pm 0.01$ & $0.02 \pm 0.01$ \\
\hline Eastern & $0.04 \pm 0.07$ & $0.24 \pm 0.07$ & $0.04 \pm 0.01$ & $0.02 \pm 0.01$ & $0.02 \pm 0.01$ & $0.02 \pm 0.01$ \\
\hline \multicolumn{7}{|l|}{ Camphene } \\
\hline Western & $0.01 \pm 0.01$ & $0.05 \pm 0.01$ & ND & ND & $0.03 \pm 0.01$ & $0.03 \pm 0.01$ \\
\hline Eastern & $0.06 \pm 0.06$ & $0.26 \pm 0.06$ & $0.02 \pm 0.007$ & $0.02 \pm 0.007$ & $0.01 \pm 0.003$ & $0.008 \pm 0.003$ \\
\hline \multicolumn{7}{|l|}{$\delta$-carene } \\
\hline Western & $0.03 \pm 0.02$ & $0.05 \pm 0.02$ & ND & ND & $0.07 \pm 0.02$ & $0.06 \pm 0.02$ \\
\hline Eastern & $0.002 \pm 0.03$ & $0.09 \pm 0.03$ & $0.07 \pm 0.04$ & $0.05 \pm 0.04$ & $0.02 \pm 0.01$ & $0.01 \pm 0.01$ \\
\hline \multicolumn{7}{|l|}{ Limonene } \\
\hline Western & $0.01 \pm 0.003$ & $0.02 \pm 0.002$ & ND & ND & $0.03 \pm 0.01$ & $0.05 \pm 0.01$ \\
\hline Eastern & $0.02 \pm 0.02$ & $0.14 \pm 0.02$ & $0.03 \pm 0.02$ & $0.07 \pm 0.02$ & $0.008 \pm 0.002$ & $0.008 \pm 0.002$ \\
\hline
\end{tabular}

Notes: Boldface indicates significant differences $(P<0.05)$ between treatments (undamaged vs. damaged) for each monoterpene, within month and location. ND indicates that no data are available.

opposed to Western Slope pinyon emission rates, which were only about three times higher than their undamaged counterparts (Fig. 2B and A, respectively), despite the fact that Western Slope pinyons exhibited monoterpene foliar concentrations about two times greater than Eastern Slope pinyons (Fig. 2C, D). These findings are consistent with studies showing that Pinus species with high constitutive levels of monoterpene cyclase activity exhibit a relatively low wounding-induced response (Lewinsohn et al. 1991). It is difficult to assess whether emissions were due to de novo production of monoterpenes or if compounds were transported from other plant tissues (Johnson and Croteau 1987). However, the significant increases in herbivore-induced emission rates at both sites occurred despite similar foliar monoterpene concentrations between undamaged and herbivoredamaged pinyons (Fig. 2C, D). These results are similar to those reported for Pinus ponderosa, which exhibited an increase in monoterpene synthase activity that resulted in high emission rates with no net effect on foliar monoterpene pool size due to the relative balance between synthesis and loss (Litvak and Monson 1998).

Total monoterpene emission rates from pinyons on the Western Slope tracked the mid-summer temperature and precipitation dynamics (Fig. 2A), while a pronounced mid-summer drought resulted in the low emission rates from both undamaged and damaged pinyons on the Eastern Slope (Fig. 2B). Data suggest that large herbivore-induced monoterpene emission rates early in the growing season may explain the significantly lower total monoterpene foliar concentrations observed in previously damaged Eastern Slope pinyons during mid-summer, particularly if needle monoterpenes are derived from the same foliar pool (Fig. 2D). Despite potential herbivore-induced enzymatic up-regulation earlier in the season, this effect may have been event-specific and not reflected throughout the remainder of the growing season. Instead, low foliar concentrations in previously damaged pinyons during mid-summer are assumed to reflect a trade-off with the early-season losses. While monoterpene synthesis may be up-regulated to keep pace with previous evaporative losses (Constable et al. 1999), carbon may be preferentially allocated toward replacing lost leaf tissue as opposed to an investment in defense (Bryant et al. 1983). Furthermore, these seasonally low emission rates occurred when temperatures were high, despite the wellestablished short-term exponential relationship that exists between temperature and monoterpene emissions (Tingey et al. 1980, Guenther et al. 1993). This response has also been noted in other studies investigating monoterpene emissions (Valentini et al. 1997, Niinemets et al. 2002, Niinemets et al. 2004), collectively demonstrating the important role of seasonal water availability, and potentially stomatal conductance, in controlling monoterpene emissions.

Although limited water availability resulted in a decrease in monoterpene emissions, foliar concentra- 
TABle 1. Extended.

\begin{tabular}{lcccc}
\hline \hline \multicolumn{2}{c}{ August } & & \multicolumn{2}{c}{ September } \\
\cline { 1 - 2 } Undamaged & Damaged & & Undamaged & Damaged \\
\hline & & & \\
$0.53 \pm 0.19$ & $0.49 \pm 0.19$ & & $0.10 \pm 0.03$ & $0.10 \pm 0.03$ \\
$\mathbf{0 . 5 0} \pm \mathbf{0 . 1 8}$ & $\mathbf{1 . 0 4} \pm \mathbf{0 . 1 7}$ & & $0.27 \pm 0.09$ & $0.51 \pm 0.09$ \\
& & & \\
$0.04 \pm 0.02$ & $0.05 \pm 0.02$ & & $0.01 \pm 0.004$ & $0.01 \pm 0.004$ \\
$0.06 \pm 0.02$ & $0.08 \pm 0.02$ & & $0.05 \pm 0.01$ & $0.05 \pm 0.01$ \\
& & & \\
$0.08 \pm 0.11$ & $0.21 \pm 0.11$ & & $0.02 \pm 0.01$ & $0.02 \pm 0.01$ \\
$0.06 \pm 0.02$ & $0.08 \pm 0.02$ & & $0.05 \pm 0.01$ & $0.04 \pm 0.01$ \\
& & & \\
$0.03 \pm 0.01$ & $0.03 \pm 0.01$ & $0.02 \pm 0.004$ & $0.01 \pm 0.004$ \\
$0.04 \pm 0.01$ & $0.04 \pm 0.01$ & $0.04 \pm 0.01$ & $0.03 \pm 0.01$ \\
& & & \\
$0.02 \pm 0.01$ & $0.03 \pm 0.01$ & $0.01 \pm 0.001$ & $0.01 \pm 0.001$ \\
$0.02 \pm 0.006$ & $0.03 \pm 0.006$ & $0.02 \pm 0.003$ & $0.02 \pm 0.003$ \\
& & & \\
$0.04 \pm 0.02$ & $0.05 \pm 0.02$ & $0.01 \pm 0.01$ & $0.01 \pm 0.01$ \\
$\mathbf{0 . 0 5} \pm \mathbf{0 . 0 2}$ & $\mathbf{0 . 1 5} \pm \mathbf{0 . 0 2}$ & $0.05 \pm 0.02$ & $0.09 \pm 0.02$ \\
& & & \\
$0.02 \pm 0.01$ & $0.03 \pm 0.01$ & $0.005 \pm 0.001$ & $0.005 \pm 0.001$ \\
$0.03 \pm 0.01$ & $0.05 \pm 0.009$ & $0.01 \pm 0.002$ & $0.02 \pm 0.002$ \\
\hline
\end{tabular}

tions did not change in response to mid-summer drought conditions. This finding presents an interesting comparison to other studies that have noted relationships among hydrological variables and monoterpene concentrations in conifers. For example, Hodges and Lorio (1975) and Lorio and Sommers (1986) noted an increase in oleoresin synthesis and monoterpene hydrocarbons in Pinus taeda exposed to moderate water stress. We did not observe a significant increase in Pinus edulis monoterpene concentration in relation to water stress as summer progressed, probably due to the droughttolerant nature of $P$. edulis compared to most other pines. This suggests that resource allocation patterns in response to drought may be species specific, with the stored quantity of monoterpenes depending more on species' genetic traits than on environmental conditions altering the carbon source-sink balance (Penuelas and Estiarte1998, Llusià et al. 2006).

A number of studies have stressed the importance of water availability on monoterpene emissions (Bertin and Staudt 1996, Kesselmeier and Staudt 1999, Staudt et al. 2000), which may be especially important on the Eastern Slope of the Southern Rocky Mountains, where the dominant precipitation events occur during late summer when evaporative demand is high. With the onset of Eastern Slope monsoon rains, not only did monoterpene emissions increase significantly, but also previously damaged pinyons had significantly higher emission rates compared to undamaged pinyons. These results suggest an interactive effect between previous herbivory and release from drought stress rather than higher average temperature or foliar concentrations, both of which decreased in August. This difference in monoterpenes emissions between previously damaged and undamaged pinyons also cannot be explained solely by differences in carbon metabolism after the monsoon, as both net $\mathrm{CO}_{2}$ assimilation $(A)$ and stomatal conductance rates $\left(g_{\mathrm{s}}\right)$ significantly increased from July to August in both damaged and undamaged pinyons (Fig. 1B, D). Average rates of $A$ between $\sim 2.5$ and $0.5 \mu \mathrm{mol} \quad \mathrm{CO}_{2} \cdot \mathrm{m}^{-2} \cdot \mathrm{s}^{-1}$ following weeks with high temperatures and low levels of precipitation at both sampling sites are similar to the $A$ range reported by Adams et al. (2009) for P. edulis, 3.0-0.5 $\mu \mathrm{mol} \mathrm{CO} \mathrm{CO}_{2} \cdot \mathrm{m}^{-2} \cdot \mathrm{s}^{-1}$, following a few weeks of simulated drought. The lack of relationship between monoterpene emissions and $A$ is consistent with studies showing that the relatively large monoterpene storage pool in the resin ducts of conifers from which emissions arise do not strongly depend on recent photoassimlates (Lerdau and Gray 2003). Previous studies have demonstrated no relationship between monoterpene emission rates and $g_{\mathrm{s}}$ in conifers (Lerdau et al. 1994, Lerdau et al. 1997), although monthly averaged conductance follows similar trends with monthly averaged monoterpene emissions here. Lamb et al. (1985) measured $\alpha$-pinene emissions within a coniferous forest using enclosure techniques and found that branches wetted by rain or dew exhibited emissions about one order of magnitude greater than those measured from dry branches. Similarly, more recent work has demonstrated that monoterpene emission rates under high-humidity conditions may be enhanced by swelling and subsequent lysing of the structures containing monoterpene pools (Loreto and Schnitzler 2010). Thus, water relations and stomatal conductance may help to explain monoterpene emission patterns on the Eastern Slope. However, these factors do not fully describe the mechanisms underlying the significantly higher emissions observed from previously damaged trees, suggesting that an additional biochemical explanation may be at play, potentially via a delayed-induced response.

\section{Monoterpene emissions and foliar concentrations: atmospheric and ecological consequences}

Our results are relevant to the development of vegetation emission models, which have become an important component of regional-to-global atmospheric chemistry modeling (Fehsenfeld et al. 1992, Guenther et al. 2000, Liao et al. 2007, Peñuelas and Staudt 2010). Although some atmospheric models consider the influence of conifer herbivory on tropospheric chemistry, algorithms are based on short-term effects and simulated herbivory. Our data suggest that herbivory will episodically increase the total monoterpene emission rates from pinyon, probably leading to an enhanced oxidative capacity of the local troposphere (Litvak et al. 1999). Furthermore, these higher emission rates are driven by specific compounds (Table 1). Although all monoterpenes 
TABLE 2. Foliar concentrations (mean $\pm \mathrm{SE}$ ) of individual monoterpene compounds ( $\mathrm{mg} / \mathrm{g}$ fresh mass) from undamaged and herbivore-damaged P. edulis trees throughout the 2009 growing season on the Western Slope and 2008 growing season on the Eastern Slope of the Rocky Mountains in southern Colorado, USA.

\begin{tabular}{|c|c|c|c|c|c|c|}
\hline \multirow[b]{2}{*}{ Monoterpene } & \multicolumn{2}{|c|}{ May } & \multicolumn{2}{|c|}{ June } & \multicolumn{2}{|c|}{ July } \\
\hline & Undamaged & Damaged & Undamaged & Damaged & Undamaged & Damaged \\
\hline \multicolumn{7}{|l|}{$(-)$ - $\alpha$-pinene } \\
\hline Western & $1.47 \pm 0.28$ & $1.79 \pm 0.28$ & ND & ND & $1.60 \pm 0.28$ & $1.30 \pm 0.28$ \\
\hline Eastern & $0.78 \pm 0.10$ & $0.55 \pm 0.10$ & $0.95 \pm 0.11$ & $0.77 \pm 0.11$ & $0.78 \pm 0.10$ & $0.55 \pm 0.10$ \\
\hline \multicolumn{7}{|l|}{$(+)$ - $\alpha$-pinene } \\
\hline Western & $3.97 \pm 0.62$ & $3.42 \pm 0.61$ & ND & ND & $3.26 \pm 0.62$ & $2.10 \pm 0.63$ \\
\hline Eastern & $1.31 \pm 0.26$ & $0.90 \pm 0.26$ & $1.59 \pm 0.28$ & $1.42 \pm 0.29$ & $1.78 \pm 0.29$ & $1.30 \pm 0.29$ \\
\hline \multicolumn{7}{|l|}{$\beta$-pinene } \\
\hline Western & $1.35 \pm 0.20$ & $1.89 \pm 0.20$ & ND & ND & $1.27 \pm 0.21$ & $0.84 \pm 0.21$ \\
\hline Eastern & $1.05 \pm 0.25$ & $0.80 \pm 0.25$ & $1.35 \pm 0.28$ & $0.90 \pm 0.29$ & $1.24 \pm 0.30$ & $0.64 \pm 0.29$ \\
\hline \multicolumn{7}{|l|}{$\beta$-myrcene } \\
\hline Western & $1.00 \pm 0.11$ & $0.77 \pm 0.11$ & ND & ND & $0.90 \pm 0.11$ & $0.48 \pm 0.11$ \\
\hline Eastern & $0.57 \pm 0.06$ & $0.34 \pm 0.05$ & $0.67 \pm 0.06$ & $0.44 \pm 0.06$ & $0.74 \pm 0.06$ & $0.43 \pm 0.06$ \\
\hline \multicolumn{7}{|l|}{$\beta$-phellandrene } \\
\hline Western & $0.14 \pm 0.02$ & $0.13 \pm 0.02$ & ND & ND & $0.13 \pm 0.02$ & $0.07 \pm \mathbf{0 . 0 2}$ \\
\hline Eastern & $0.08 \pm 0.01$ & $0.05 \pm 0.01$ & $0.09 \pm 0.01$ & $0.07 \pm 0.01$ & $0.11 \pm 0.01$ & $0.07 \pm 0.01$ \\
\hline \multicolumn{7}{|l|}{ Camphene } \\
\hline Western & $0.07 \pm 0.01$ & $0.07 \pm 0.01$ & ND & ND & $0.07 \pm 0.01$ & $0.05 \pm 0.01$ \\
\hline Eastern & $0.07 \pm 0.01$ & $0.05 \pm 0.01$ & $0.07 \pm 0.01$ & $0.06 \pm 0.01$ & $0.07 \pm 0.01$ & $0.05 \pm 0.01$ \\
\hline \multicolumn{7}{|l|}{ (-)-limonene } \\
\hline Western & $0.17 \pm 0.02$ & $0.18 \pm 0.02$ & ND & ND & $0.15 \pm 0.02$ & $0.12 \pm 0.02$ \\
\hline Eastern & $0.13 \pm 0.02$ & $0.06 \pm 0.02$ & $0.07 \pm 0.02$ & $0.09 \pm 0.03$ & $0.10 \pm 0.03$ & $0.08 \pm 0.03$ \\
\hline
\end{tabular}

Notes: Boldface indicates significant differences $(P<0.05)$ between treatments (undamaged vs. damaged) for each monoterpene, within month and location. ND indicates that no data are available.

should react via a similar pathway, given the same conditions in the atmosphere, they each have different reactivity rates with various atmospheric constituents (e.g., $\mathrm{OH}^{-}, \mathrm{NO}_{\mathrm{x}}, \mathrm{O}_{3}$, and so forth), resulting in diverse secondary products with important feedbacks on regional atmospheric chemistry (Atkinson et al. 1986). For example, $\alpha$-pinene comprises $\sim 42 \%$ of the total monoterpene emissions measured from both damaged and undamaged pinyons at the Eastern Slope site during early season herbivory. However, the proportion of $\alpha$-pinene emitted increased throughout the season, peaking with the onset of the monsoon season in August and comprising $64 \%$ and $70 \%$ of the total emissions from undamaged and previously damaged pinyons, respectively (Table 1). $\beta$-pinene is the second largest constituent of total monoterpene emissions in both undamaged and damaged pinyons during early-season herbivory, making up $24 \%$ and $17 \%$ of the total emissions, respectively. However, in contrast to $\alpha$-pinene, the proportion of $\beta$ pinene emissions decreased throughout the season in both undamaged and previously damaged pinyons, with the lowest levels observed during the late-summer monsoon ( $\sim 8 \%$ and $5 \%$, respectively). $\beta$-pinene has a rate constant with $\mathrm{OH}^{-}$that is nearly 1.5 times greater than that of $\alpha$-pinene $\left(8.0 \times 10^{-11} \mathrm{~cm}^{3} \cdot\right.$ molecule $^{-1} \cdot \mathrm{s}^{-1}$ vs. $5.5 \times 10^{-11}$ $\mathrm{cm}^{3} \cdot$ molecule $^{-1} \cdot \mathrm{s}^{-1}$ at $294 \mathrm{~K}$; Atkinson et al. 1986). Thus, each compound's effect on the oxidative state of the regional atmosphere varies as a function of its reactivity, seasonality, and the tree's herbivore status. Other minor constituents of pinyon monoterpene emissions also change in their relative proportions throughout the growing season and some have rate constants an order of magnitude greater than those reported for $\alpha$-pinene and $\beta$-pinene (Atkinson et al. 1986). Therefore, it is worth considering changes in individual compounds in response to herbivory and seasonality when assessing potential impacts of monoterpene emissions on atmospheric processes.

The characteristic lifetimes of individual monoterpenes in the atmosphere have consequences for both atmospheric chemistry and ecological signaling. Studies have shown that herbivore-induced monoterpene emissions can deter oviposition in generalists while stimulating oviposition in specialist herbivores (Leather 1987, Binder and Robbins 1997, Shu et al. 2004, Grant et al. 2007). Moreover, many plant species employ induced volatile monoterpene cues as indirect defenses, recruiting the natural enemies of the herbivores that attack them (DeMoraes et al. 1998). In our study, we observed a burst in monoterpene emissions with the onset of the late-summer monsoons when adult moths are searching for oviposition sites and parasitoid pressures increase. Previously damaged trees exhibited significantly higher total monoterpene emissions, driven by increased $\alpha$ pinene and $\delta$-carene emission rates. The increase in emissions of these compounds may play a role in conveying important host quality information to $L$. ingens moths. However, these compounds could also 
TABLE 2. Extended.

\begin{tabular}{lcccc}
\hline \hline \multicolumn{2}{c}{ August } & & \multicolumn{2}{c}{ September } \\
\cline { 1 - 1 } Undamaged & Damaged & & Undamaged & Damaged \\
\hline & & & \\
$1.29 \pm 0.29$ & $1.66 \pm 0.28$ & & $1.50 \pm 0.28$ & $1.62 \pm 0.28$ \\
$0.81 \pm 0.11$ & $0.53 \pm 0.11$ & $1.02 \pm 0.11$ & $0.81 \pm 0.11$ \\
& & & \\
$2.17 \pm 0.64$ & $2.95 \pm 0.63$ & & $2.80 \pm 0.62$ & $3.32 \pm 0.63$ \\
$1.28 \pm 0.29$ & $0.74 \pm 0.29$ & & $1.35 \pm 0.28$ & $1.42 \pm 0.29$ \\
& & & \\
$0.69 \pm 0.21$ & $1.02 \pm 0.21$ & & $1.18 \pm 0.21$ & $1.62 \pm 0.21$ \\
$0.89 \pm 0.29$ & $0.63 \pm 0.29$ & & $0.81 \pm 0.28$ & $1.19 \pm 0.29$ \\
& & & \\
$0.70 \pm 0.11$ & $0.67 \pm 0.11$ & & $0.95 \pm 0.11$ & $0.59 \pm 0.11$ \\
$\mathbf{0 . 5 5} \pm \mathbf{0 . 0 6}$ & $\mathbf{0 . 3 0} \pm \mathbf{0 . 0 6}$ & $\mathbf{0 . 6 8} \pm \mathbf{0 . 0 6}$ & $\mathbf{0 . 4 5} \pm \mathbf{0 . 0 6}$ \\
& & & \\
$0.08 \pm 0.02$ & $0.08 \pm 0.02$ & & $0.14 \pm 0.02$ & $0.10 \pm 0.02$ \\
$0.08 \pm 0.01$ & $0.04 \pm 0.01$ & & $0.09 \pm 0.01$ & $0.06 \pm 0.01$ \\
& & & \\
$0.06 \pm 0.01$ & $0.06 \pm 0.01$ & $0.07 \pm 0.01$ & $0.07 \pm 0.01$ \\
$0.06 \pm 0.01$ & $0.04 \pm 0.10$ & $0.06 \pm 0.10$ & $0.04 \pm 0.10$ \\
& & & \\
$0.10 \pm 0.02$ & $0.14 \pm 0.02$ & $0.17 \pm 0.02$ & $0.12 \pm 0.02$ \\
$0.07 \pm 0.03$ & $0.05 \pm 0.03$ & $0.06 \pm 0.03$ & $0.08 \pm 0.03$ \\
\hline & & &
\end{tabular}

function as pinyon indirect defenses if exploited as host location cues by the parasitoids that attack $L$. ingens (Meteorus euschausiae), which prefer to parasitize early larval instars (A. M. Trowbridge, personal observation). Although the functional role of these individual volatiles has yet to be determined in this system, it is likely that the relative abundances of monoterpenes and their reactivity rates with oxidizing agents in the atmosphere will have consequences for pinyon-herbivore-parasitoid interactions and chemically mediated herbivore population controls.

Although many studies have shown herbivory to result in an increased production of secondary compounds, and thus plant resistance, this is not always the case (Williams and Myers 1984). We observed a trend toward lower total monoterpene concentration in pinyons during and following herbivore feeding on the Eastern Slope, probably resulting from high emission rates. The relatively low foliar monoterpene concentrations resulting from herbivory could potentially increase the susceptibility of damaged pinyons to tiger moth attack by the next generation, but the associated high emissions may also serve as a highly effective indirect defense strategy by recruiting the herbivore's natural enemy. Thus, herbivores may be faced with a choice between undamaged trees with high foliar defenses but enemy-free space, or poorly defended, damaged trees that may also effectively recruit parasitoids. To understand the role that monoterpenes play in mediating multi-trophic-level interactions in this system, future work should focus on the effect of herbivore $\times$ droughtinduced monoterpene foliar chemistry and emissions on herbivore and parasitoid preference and behavior.

Experimental results suggest an additional interplay between herbivory and ecohydrology; herbivore-damaged pinyons on the Eastern Slope did not demonstrate a significant decline in $A$ or $g_{s}$ from May to July (Nabity et al. 2009), suggesting that the moderate loss of leaf area from herbivory may have conferred whole-tree water savings (Pataki et al. 1998) and resulted in improved plant function relative to undamaged pinyons. Under drought conditions, this increase in water savings may have enabled a stronger metabolic response with release from stress, including increased emissions later in the season as a result of delayed herbivore induction. This mechanism has been proposed in various species over different time scales (Tuomi et al. 1990) and is supported by the observed increase in monoterpene emissions in the absence of herbivory or changes in foliar monoterpene concentration later in the season. Higher monoterpene emissions from previously damaged pinyons may then be a combination of droughtdelayed stimulation of induced monoterpene synthesis and improved water relations. In other words, pinyons are potentially "conditioned" to express defenses later in the season, perhaps through biosynthetic processes and physiological states that were suppressed during stress and are up-regulated upon release from drought (Niinemets 2010).

\section{CONCLUSION}

This study provides a new perspective that contrasts with the traditional framework within which studies investigate various controls over monoterpene production. Our results suggest that abiotic and biotic controls over pinyon monoterpene emissions and foliar concentrations show notable interactive effects and trade-offs in relative importance throughout the season. Data suggest a strong influence of water availability and herbivory on pinyon chemistry, which may offer a more mechanistic view of how insects exacerbate droughtinduced pinyon mortality through delayed induced plant chemical responses. In addition to offering insight into the complex feedbacks that exist between multiple drivers in altering foliar and volatile monoterpenes during outbreaks, our results have potentially important consequences for atmospheric processes and higher trophic level interactions in pinyon-juniper ecosystems. Future studies examining the effects of herbivoreinduced pinyon chemistry on insect preference and performance will aid in our explanation of herbivore population outbreaks in this system.

\section{ACKNOWLEDGMENTS}

Funding was provided by Grant 0919189 from the NSF Division of Atmospheric and Geospace Sciences awarded to R. K. Monson and a Beverly Sears Research Grant and summer research fellowship awarded to A. M. Trowbridge through the University of Colorado Graduate School and 
Department of Ecology and Evolutionary Biology, respectively We thank Nate Monson, Lindsay Young, Ryan Weaver, and Jeff Beauregard for their many hours of help with fieldwork and Ken Keefover-Ring for GC-MS assistance.

\section{Literature Cited}

Adams, H. D., M. Guardiola-Claramonte, G. A. BarronGafford, J. Camilo Villegas, D. D. Breshears, C. B. Zou, P. A. Troch, and T. E. Huxman. 2009. Temperature sensitivity of drought-induced tree mortality portends increased regional die-off under global-change-type drought. Proceedings of the National Academy of Sciences USA 106: 7063-7066.

Atkinson, N., S. M. Aschmann, and J. N. Pitts. 1986. Rate constants for the gas phase reactions of the $\mathrm{OH}$ radical with a series of monoterpenes at $294 \pm 1 \mathrm{~K}$. International Journal of Chemical Kinetics 18:287-299.

Bertin, N., and M. Staudt. 1996. Effect of water stress on monoterpene emissions from young potted holm oak (Quercus ilex L.) trees. Oecologia 107:456-462.

Binder, B. F., and J. C. Robbins. 1997. Effect of terpenoids and related compounds on the oviposition behavior of the European corn borer Ostrinia nubilalis (Lepidoptera: Pyralidae). Journal of Agricultural and Food Chemistry 45:980984.

Brown, J. H., T. G. Whitham, S. K. Morgan Ernest, and C. A. Gehring. 2001. Complex species interactions and the dynamics of ecological systems: long-term experiments. Science 293:643-50.

Bryant, J. P., F. S. Chapin, III, and D. R. Klein. 1983. Carbon/ nutrient balance of boreal plants in relation to vertebrate herbivory. Oikos 40:357-368.

Chen, J. M., P. M. Rich, S. T. Gower, J. M. Norman, and S. Plummer. 1997. Leaf area index of boreal forests: Theory, techniques, and measurements. Journal of Geophysical Research: Atmospheres (1984-2012) 102:29429-29443.

Cobb, N. S., S. Mopper, C. A. Gehring, M. Caouette, K. M. Christensen, and T. G. Whitham. 1997. Increased moth herbivory associated with environmental stress of pinyon pine at local and regional levels. Oecologia 109:389.

Constable, J. V. H., A. B. Guenther, D. S. Schimel, and R. K. Monson. 1999. Modelling changes in VOC emission in response to climate change in the continental United States. Global Change Biology 5:791-806.

DeMoraes, C. M., W. J. Lewis, P. W. Paré, H. T. Alborn, and J. H. Tumlinson. 1998. Herbivore-infested plants selectively attract parasitoids. Nature 393:570-573.

Fehsenfeld, F., et al. 1992. Emissions of volatile organic compounds from vegetation and the implications for atmospheric chemistry. Global Biogeochemical Cycles 6: 389-430.

Grant, G. G., J. Guo, L. MacDonald, and M. D. Coppens. 2007. Oviposition response of spruce budworm (Lepidoptera: Tortricidae) to host terpenes and green-leaf volatiles. Canadian Entomologist 139:564-575.

Guenther, A., C. Geron, T. Pierce, B. Lamb, P. Harley, and R. Fall. 2000. Natural emissions of non-methane volatile organic compounds, carbon monoxide, and oxides of nitrogen from North America. Atmospheric Environment 34:2205-2230.

Guenther, A. B., P. R. Zimmerman, P. C. Harley, R. K. Monson, and R. Fall. 1993. Isoprene and monoterpene emission rate variability: Model evaluations and sensitivity analyses. Journal of Geophysical Research 98:12609-12612.

Gutbrodt, B., K. Mody, and S. Dorn. 2011. Drought changes plant chemistry and causes contrasting responses in lepidopteran herbivores. Oikos 120:1732-1740.

Hakola, H., V. Tarvainen, J. Bäck, H. Ranta, B. Bonn, J. Rinne, and M. Kulmala. 2006. Seasonal variation of mono- and sesquiterpene emission rates of Scots pine. Biogeosciences 3:93-101.
Hodges, J. D., and P. L. Lorio. 1975. Moisture stress and composition of xylem oleoresin in loblolly pine. Forest Science 21:283-290.

Johnson, M. A., and R. Croteau. 1987. Biochemistry of conifer resistance to bark beetles and their fungal symbionts. Pages 76-91 in G. Fuller and W. D. Nes, editors. Ecology and metabolism of plant lipids. ACS Symposium Series 325. American Chemical Society, Washington, D.C., USA.

Kesselmeier, J., and M. Staudt. 1999. Biogenic volatile organic compounds (VOC): An overview on emission, physiology and ecology. Journal of Atmospheric Chemistry 33:23-88.

Lamb, B., H. Westberg, G. Allwine, and T. Quarles. 1985. Biogenic hydrocarbon emissions from deciduous and coniferous trees in the United States. Journal of Geophysical Research: Atmospheres 90:2380-2390.

Lavoir, A. V., M. Staudt, J. P. Schnitzler, D. Landais, F. Massol, A. Rocheteau, R. Rodriguez, I. Zimmer, and S. Rambal. 2009. Drought reduced monoterpene emissions from the evergreen Mediterranean oak Quercus ilex: results from a throughfall displacement experiment. Biogeosciences 6:1167-1180.

Leather, S. R. 1987. Pine monoterpenes stimulate oviposition in the pine beauty moth, Panolis flammea. Entomologia Experimentalis et Applicata 43:295-303.

Lerdau, M., B. Dilts, H. Westberg, B. K. Lamb, and J. Allwine. 1994. Monoterpene emission from ponderosa pine. Journal of Geophysical Research: Atmospheres 99:16609-16615.

Lerdau, M., and D. Gray. 2003. Ecology and evolution of lightdependent and light-independent phytogenic volatile organic carbon. New Phytologist 157:199-211.

Lerdau, M., M. Litvak, P. Palmer, and R. Monson. 1997. Controls over monoterpene emissions from boreal forest conifers. Tree Physiology 17:563-569.

Lewinsohn, E., M. Gijzen, and R. Croteau. 1991. Defense mechanisms of conifers differences in constitutive and wound-induced monoterpene biosynthesis among species. Plant Physiology 96:44-49.

Liao, H., D. K. Henze, J. H. Seinfeld, S. Wu, and L. J. Mickley. 2007. Biogenic secondary organic aerosol over the United States: Comparison of climatological simulations with observations. Journal of Geophysical Research: Atmospheres (1984-2012) 112:D06201.

Litvak, M. E., S. Madronich, and R. K. Monson. 1999. Herbivore-induced monoterpene emissions from coniferous forests: Potential impact on local tropospheric chemistry. Ecological Applications 9:1147-1159.

Litvak, M. E., and R. K. Monson. 1998. Patterns of induced and constitutive monoterpene production in conifer needles in relation to insect herbivory. Oecologia 114:531-540.

Llusià, J., and J. Peñuelas. 1998. Changes in terpene content and emission in potted Mediterranean woody plants under severe drought. Canadian Journal of Botany 76:1366-1373.

Llusià, J., J. Peñuelas, G. A. Alessio, and M. Estiarte. 2006. Seasonal contrasting changes of foliar concentrations of terpenes and other volatile organic compound in four dominant species of a Mediterranean shrubland submitted to a field experimental drought and warming. Physiologia Plantarum 127:632-649.

Loreto, F., P. Nascetti, A. Graverini, and M. Mannozzi. 2000. Emission and content of monoterpenes in intact and wounded needles of the Mediterranean pine, Pinus pinea. Functional Ecology 14:589-595.

Loreto, F., and J. P. Schnitzler. 2010. Abiotic stresses and induced BVOCs. Trends in Plant Science 15:154-166.

Lorio, P. L., and R. A. Sommers. 1986. Evidence of competition for photosynthates between growth processes and oleoresin synthesis in Pinus taeda L. Tree Physiology 2: 301-306.

Mattson, W. J., and R. A. Haack. 1987. The role of drought in outbreaks of plant-eating insects. BioScience 37:110-118. 
Mueller, R. C., C. M. Scudder, M. E. Porter, R. Talbot Trotter, C. A. Gehring, and T. G. Whitham. 2005. Differential tree mortality in response to severe drought: Evidence for longterm vegetation shifts. Journal of Ecology 93:1085-1093.

Nabity, P. D., J. A. Zavala, and E. H. DeLucia. 2009. Indirect suppression of photosynthesis on individual leaves by arthropod herbivory. Annals of Botany 103:655-63.

Niinemets, Ü. 2010. Mild versus severe stress and BVOCs: thresholds, priming and consequences. Trends in Plant Science 15:145-153.

Niinemets, Ü., F. Loreto, and M. Reichstein. 2004. Physiological and physiochemical controls on foliar volatile organic compound emissions. Trends in Plant Science 9:180-186.

Niinemets, Ü., M. Reichstein, M. Staudt, G. Seufert, and J. D. Tehnunen. 2002. Stomatal constraints may affect emission of oxygenated monoterpenoids from the foliage of Pinus pinea. Plant Physiology 130:1371-1385.

Ortega, J., D. Helmig, R. W. Daly, D. M. Tanner, A. B. Guenther, and J. D. Herrick. 2008. Approaches for quantifying reactive and low-volatility biogenic organic compound emissions by vegetation enclosure techniquesPart B: Applications. Chemosphere 72:365-380.

Pataki, D. E., R. Oren, and D. T. Tissue. 1998. Elevated carbon dioxide does not affect average canopy stomatal conductance of Pinus taeda L. Oecologia 117:47-52.

Peñuelas, J., and M. Staudt. 2010. BVOCs and global change. Trends in Plant Science 15:133-144.

Powell, J. A., and P. A. Opler. 2009. Moths of Western North America. University of California Press, Berkeley, California, USA.

Schönwitz, R., K. Lohwasser, M. Kloos, and H. Ziegler. 1990. Seasonal variation in the monoterpenes in needles of Picea abies (L.) Karst. Trees 4:34-40.

Shu, S., G. G. Grant, D. Langevin, D. A. Lombardo, and L. MacDonald. 2004. Oviposition and electroantennogram responses of Dioryctria abietivorella (Lepidoptera: Pyralidae) elicited by monoterpenes and enantiomers from eastern white pine. Journal of Chemical Ecology 23:1573-1561.

Staudt, M., N. Bertin, B. Frenzel, and G. Seufert. 2000. Seasonal variation in amount and composition of monoterpenes emitted by young Pinus pinea trees-Implications for emission modeling. Journal of Atmospheric Chemistry 35: 77-99.

Staudt, M., N. Bertin, U. Hansen, G. Seufert, P. Cicciolij, P. Foster, B. Frenzel, and J.-L. Fugit. 1997. Seasonal and diurnal patterns of monoterpene emissions from Pinus pinea (L.) under field conditions. Atmospheric Environment 31: $145-156$.

Staudt, M., S. Rambal, R. Joffre, and J. Kesselmeier. 2002. Impact of drought on seasonal monoterpene emissions from Quercus ilex in southern France. Journal of Geophysical Research 107:4602.

Tingey, D. T., M. Manning, L. C. Grothaus, and W. F. Burns. 1980. Influence of light and temperature on monoterpene emission rates from slash pine. Plant Physiology 65:797-801.

Trapp, S., and R. Croteau. 2001. Defensive resin biosynthesis in conifers. Annual Review of Plant Biology 52:689-724.

Tuomi, J., P. Niemelä, and S. Sirén. 1990. The Panglossian paradigm and delayed inducible accumulation of foliar phenolics in mountain birch. Oikos 59:399-410.

Valentini, R., S. Greco, G. Seufert, N. Bertin, P. Ciccioli, A. Cecinato, E. Brancaleoni, and M. Frattoni. 1997. Fluxes of biogenic VOC from Mediterranean vegetation by trap enrichment relaxed eddy accumulation. Atmospheric Environment 31:229-238.

Waring, G. L., and N. S. Cobb. 1992. The impact of plant stress on herbivore population dynamics. Pages $167-226$ in E. A. Bernays, editor. Insect-plant interactions. CRC Press, Boca Raton, Florida, USA.

West, N. E. 1999. Distribution, composition, and classification of current juniper-pinyon woodlands and savannas across western North America. Pages 20-23 in S. B. Monsen and R. Stevens, editors. Proceedings: Ecology and management of pinyon-juniper communities within the interior West. USDA Forest Service Proceedings RMRS-P-9, Ogden, Utah, USA.

Williams, K. S., and J. H. Myers. 1984. Previous herbivore attack of red alder may improve food quality for fall webworm larvae. Oecologia 63:166-170.

Yuan, J. S., S. J. Himanen, J. K. Holopainen, F. Chen, and C. N. Stewart, Jr. 2009. Smelling global climate change: mitigation of function for plant volatile organic compounds. Trends in Ecology and Evolution 24:323-331.

\section{Supplemental Material}

\section{Appendix A}

Mean monthly temperature and the monthly sum of precipitation from long-term Colorado Climate Center meteorological observations near the study sites (Ecological Archives E095-139-A1).

\section{Appendix B}

Description of methods for determining leaf area using volume displacement (Ecological Archives E095-139-A2).

\section{Appendix C}

Photos detailing the dynamic headspace chamber design and its use in the field (Ecological Archives E095-139-A3).

\section{Appendix D}

Methods describing volatile chemical analysis using thermal desorption (Ecological Archives E095-139-A4).

\section{Appendix E}

Description of monoterpene chemical analysis of pinyon foliar samples (Ecological Archives E095-139-A5).

\section{Appendix F}

Total monoterpene basal emission rates (BERs) and total foliar monoterpene concentrations (Ecological Archives E095-139-A6).

\section{Appendix G}

Mean individual monoterpene basal emission rates (BERs) (Ecological Archives E095-139-A7). 